\title{
RUSÇUK VE ÇEVRESINDE CEREHORLAR
}

(1694-1698)

\section{Kamil Çolak}

\section{Öz}

Osmanlı Devleti'nde ücret karşılığı geçici olarak geri hizmetlerde kullanılan askerlere cerehor adı verilmiştir. Cerehorlar genellikle kale tamiri, yol, köprü, gemi, tabya inşası, maden ocakları, bataklık temizleme, siper kazma, gemilerde kürek çekme gibi işlerde çalıştırılmışlardır. Bu arada devlete ait bazı işlerin yapılması durumunda cerehorluktan muaf olunabilmiştir. Rusçuk şehri Tuna Nehri kıyısında yer aldığından, buradan temin edilen cerehorlar büyük ölçüde gemilerde kürek çekmişlerdir. İncelenen dönemde Avusturya ile savaşlar yapıldığından cerehorların zahire, top, asker, yaralı, hasta, değişik gıdalar, mehterhane mühimmatı ve Otağ-1 Hümayun malzemeleri gibi şeylerin taşındığı gemilerde, daha ziyade götürü usulü ortalama iki esedi kuruş ücret ile görevlendirildikleri dikkat çekmektedir. Bunların ücretleri devlet tarafından ödenmekle birlikte bazen kaza ileri gelenleri de ödemelere katkı sağlamışlardır. Rusçuk ve çevresindeki cerehorlar Müslümanlar ve gayrimüslimler arasından seçilen, daha ziyade yevmiye ile çalışan amele statüsünde gruplar gibi gözükmektedirler. Ücret karşılığı geçici olarak geri hizmetlerde kullanılan bu guruplara XVIII. yüzyıldan sonra pek rastlanmamiştır.

Anahtar Kelimeler: Osmanlı, Rusçuk, Tuna, II. Mustafa, cerehor.

Prof. Dr., Eskişehir Osmangazi Üniversitesi, Tarih Bölümü, kcolak@ogu.edu.tr 
The Cerehors Around Ruse and Its Vicinity (1694-1698)

\begin{abstract}
Cerehor is the name given to the soldiers who were used by the Ottoman State for military services at the backside of the army in return for a price temporarily. The cerehors were usually laboured in some works like restoration of fortresses, construction of road, bridge, ship, bastion and stockade, mining, cleaning of swamps, trench diging and rowing on the ships. If the people carried out some state works they could be exempted from being cerehor. As the city of Ruse was located by the River Danube, the cerehors assured from here were usually used for rowing on the ships. During the period studied there were wars with Austria so the cerehors were employed in the ships carrying grain, cannons, soldiers, wounded soldiers, patients, various foods, important materials of mehterhane and the tent of the Ottoman Sultan. These cerehors were paid on an average two esedi kuruş by the state and sometimes by the statesmen. The cerehors in Ruse seem to be a group choosed from among the muslims and non-muslims and laboured in the status of worker with a price of daily wage. These groups which were temporarily used at the backside of the army in return for a price almost ceased to appear in the registers after XVIIIth century.
\end{abstract}

Keywords: Ottoman, Ruse, The Danube, Mustafa II, cerehor. 


\section{Giriş}

Farsça' da "ücret, nafaka, maaş" anlamlarına gelen cerâ kelimesiyle, "yiyen, yiyici" anlamındaki hor kelimesinin birleşmesiyle ortaya çıkan cerehor ${ }^{1}$ kelimesi, Selçuklular'da ve özellikle Osmanlı askerî teşkilatında daha çok geri hizmetlerde geçici olarak yararlanılmış olan ücretli askerler için kullanılmıştır. ${ }^{2}$ Cerehorların Osmanlı ordusunda ilk olarak kullanılmaları muhtemelen Orhan Gazi veya ondan biraz sonraki döneme denk gelmektedir. ${ }^{3}$ Timur'a karşı yapılan 1402 yılındaki Ankara Savaşı'ndan önce cerehor adıyla Rumeli'den, hatta Bizans'tan ücretli asker toplama işi Çandarlı Ali Paşa'nın tavsiyesiyle ortaya çıkmış ve daha sonra bir askerî teşkilat halini almıştır. ${ }^{4}$ Ankara Savaşı'nda Rumeli ve Anadolu'dan, hatta İstanbul'dan temin edilen cerehorların kullanıldığı bilinmektedir. ${ }^{5}$ II. Murat döneminde düzenli birliklere ilave olarak ordu, eyaletlerden talep edilen cerehorlarla takviye edilmiştir. ${ }^{6}$ Bunlar ihtiyaca göre gençlerden toplanırdı. Yeniçeri Ocağı'nın kurulmasindan sonra garib, azeb ve canbazan taifeleri gibi eyalet askerleri gurubuna dahil olan cerehorlar, gönüllü olarak alınabildiği gibi zorlama yoluyla da toplanabilirdi. Firar olaylarını önlemek amacıyla her cerehorun bir kefili olurdu. Sonraki dönemlerde daha çok kale tamiri, ${ }^{7}$ köprü yapımı, yol inşaatı ve maden ocaklarında kullanılan cerehorlar, avarız vergisinden muaf tutulma karşılığı olarak da çalıştırılmışlardır.

1 Cerâhor, çerâhor, cerîhor, ecrîhor, cîrehor, icrâhor ve erbâb-1 uçur şeklinde "maaş alan, ücretli”, anlamında kullanımı da söz konusudur. Erkan Göksu, Türkiye Selçuklularında Ordu, Gazi Üniversitesi Sosyal Bilimler Enstitüsü, Basılmamış Doktora Tezi, Ankara 2008, s.110.

2 Abdülkadir Özcan, “Cerehor”, TDVIA, C. 7, İstanbul 1993, s.393.

3 İ. Hakkı Uzunçarşılı, Osmanlı Devleti Teşkilatından Kapukulu Ocakları, C.1, Ankara 1988, s.1.

4 Münir Aktepe, "Çandarlı Ali Paşa”, TDVIA, C.8, İstanbul 1993, s.212.

5 M. Zeki Pakalın, “Cerahor”, Osmanlı Tarih Deyimleri ve Terimleri Sözlüğ̈̈, C.1, İstanbul 2004, s.280.

6 Pál Fodor, “The Way of a Seljuq Institution to Hungary: The Cerehor", Acta Orientalia, Vol.38, No.3, 1984, s.371-374.

71516 tarihli Bosna Kanunnamesi’nde cerehorların uç bölgelerindeki kalelerin tamirinde görevlendirildikleriyle ilgili kayıtlar için bkz. Bosna-Hersek İle İlgili Arşiv Belgeleri (1516-1919), T.C. Başbakanlık Devlet Arşivleri Genel Müdürlüğü, Osmanlı Arşivi Daire Başkanlığı, Yayın No: 7, Ankara 1992, s.60, 62, 65, 70. 
Nitekim 1440'lı y1llara kadar inen cerehorluktan muafiyet belgeleri mevcuttur. ${ }^{8}$

XVI. yüzyılda cerehorların yevmiyeleri dört akçe civarındaydı. Belgelerden anlaşıldığı kadarıyla yüzyıl başlarında saray ve sur tamir ve inşaatlarında ${ }^{9}$ da çalıştırıldıkları görülen bu zümre, genellikle barış dönemlerinde ücret karşıllğ 1 , savaş dönemlerinde ise vergi muafiyeti çerçevesinde hizmet görüyordu. ${ }^{10}$ Bunun yanında yaptıkları bazı hizmetler karşıllı̆ıında cerehor olmaktan muaf olanlar da vardı. Kanuni Sultan Süleyman dönemine ait 1562 tarihli bir kayıttan anlaşıldığına göre, bir köy derbent olarak belirlendiğinde; köy ahalisi derbendi korumaları karşı1lğında avarız-1 divaniyye, tekalif-i örfiyye, kömürcülük, angarya işler, acemi ocağına çocuk verme ve cerehorluk gibi görevlerden muaf olabiliyordu. ${ }^{11} 1578$ tarihli III. Murat dönemine ait başka bir kayıtta ise stratejik açıdan önemli olan bir köprünün tamirini üstlenmek şartıyla bir grup reayanın avarız-1 divaniyye, tekalif-i örfiyye, nüzül, gılman-1 acemiyan, kürekçi ve cerehorluk gibi görevlerden muaf olabildiği dikkat çekmektedir. ${ }^{12}$ Yine III. Murat devrine ait Sirem Sancağı Mufassal tahrir defterine göre İyluk Kalesi'nin devlete ait anbarlarında önemli miktarda arpa ve erzak depolandığından, bu anbarların korunması için insana ihtiyaç duyulması üzerine çevredeki bazı köylerin ahalisinin avarız-1 divaniyye, tekalif-i örfiyye, nüzül, kale inşaat $1,{ }^{13}$ gılman-1 acemiyan ve cerehorluk gibi görev ve vergilerden muaf olmak şartıyla söz

8 Özcan, "Cerehor", s.393.

91509 y1lında meydana gelen depremlerde epeyce zarar gören İstanbul'da devlete ait yerlerin tamir ve inșa faaliyetleri için Anadolu'dan 37.000, Rumeli'den 29.000 cerehor görevlendirilmiștir. Mehmet Demirtaş, "XVI. Yüzyılda Meydana Gelen Tabii Afetlerin İstanbul'un Sosyal ve Ekonomik Hayatına Etkilerine Dair Bazı Misaller”, Atatürk Üniversitesi Sosyal Bilimler Enstitüsü Dergisi, Cilt 4, Sayı 2, 2004, s.42.

10 Özcan, “Cerehor”, s.393.

11 Uzunçarşıll, a.g.e., s.110-111.

12 Uzunçarşıll, a.g.e., s.110.

13 XVI. yüzyılda cerehorların yoğun olarak kale inşaatlarında çalıștırıldıkları görülmektedir. II. Selim döneminde, 7 Nisan 1568 tarihinde, Makarska İskelesi'nde yapılacak kale için Hersek sancağı kazalarından yeterli miktarda cerehor göndermeleri bölgedeki kadılara emredilmiştir. 7 Numaralı Mühimme Defteri (975-976/1567-1569), II, Başbakanlık Devlet Arşivleri Genel Müdürlüğü, Osmanlı Arşivi Daire Başkanlığı, Yayın Nu: 37, Ankara 1999, s.17-18. 
konusu anbarların korunması işini üstlerine almış olmaları bu guruba örnek olarak verilebilir. ${ }^{14}$

XVII. yüzyıla ait belgelere bakıldığında cerehorların seferlerde yol açmak, kale yapmak ve tamir etmek, bataklıkları temizlemek, siper kazmak, zahire ve ordu mühimmatını nakletmek, tabya ve şaranpolar yapmak, ${ }^{15}$ gemi inşasında çalışmak gibi işlerde görev aldıkları dikkat çekmektedir. Özellikle miri zahire ve top taşıyan gemilerde hizmet ettiklerine de sıkça rastlanmaktadır. Tuna Nehri'nin bazı yerlerinde girdaplar bulunduğundan cerehorlara büyük iş düşmekte, gemileri iplerle çekmek suretiyle girdabın akıntısından kurtarmaları önem arz etmekteydi. Cerehorların temin edilmesinden, ilgili bölgedeki her kazanın kad1, kethüda yeri, yeniçeri serdarı, iskele eminleri, iş erleri, ${ }^{16}$ kale ağaları ve köy zabitleri gibi görevliler sorumlu tutulurdu. ${ }^{17}$ Hizmetleri zamanla az ücret karşılığ rençberlik ve ırgatlık haline dönüşmüş olan cerehorlara XVIII. yüzyıldan sonra pek rastlanmamaktadır. ${ }^{18}$

Araştırmada 1694-1698 yıllarına ait hükümler içeren 4 numaralı Rusçuk Şer'iyye Sicili temel kaynak olarak kullanılmış, cerehorlarla ilgili literatürün katkısıyla konu analiz edilmeye çalışılmıştır.

\section{Rusçuk ve Çevresinden Cerehor Temini}

Rusçuk ve çevresinden devlete ait işler için cerehor temin edilirken dikkat çeken bazı uygulama örnekleri söz konusudur. Her şeyden önce bu işten, ilgili bölgedeki kadı ve diğer devlet memurları sorumlu tutulur, ne kadar cerehor gerekli ise temin ederek konuyla ilgili kişiye

14 Uzunçarş111, a.g.e., s.111.

151695 yılında Belgrad Muhafızı Vezir Cafer Paşa Tuna Nehri'nin kolu olan Tise Nehri kenarındaki Titel Kalesi'ni fethetmeye gittiğinde iki bin cerehor ile nehrin kenarında tabya ve şaranpolar inşa etmiştir. Bkz. Mehmet Topal, Silâhdar Fındıklılı Mehmed Ăga, Nusretnâme Tahlil ve Metin (1106-1133/1695-1721), Marmara Üniversitesi Sosyal Bilimler Enstitüsü, Basılmamış Doktora Tezi, İstanbul 2001, s.86.

16 Meryem Kaçan Erdoğan, II. Viyana Muhasarası, Marmara Üniversitesi Sosyal Bilimler Enstitüsü Basılmamış Doktora Tezi, İstanbul 2001, s.39-42.

17 Rusçuk Şer 'iyye Sicili (R), Nr. 4, v.36a.

18 Özcan, “Cerehor”, s.393. Cerehorlar XVIII. yüzyılda ücret karşılığı kanal inşaatında da çalıştırılmışlardır. Bkz. Tahir Sevinç, "Osmanlı Devleti’nin İrşeve Kanalı Projesi (1739-1741)”, History Studies, 8/9, 2013, s.2201-2216. 
teslim etmeleri emredilirdi. ${ }^{19}$ Rusçuk, Tuna Nehri kenarında bulunduğundan temin edilen cerehorlar genellikle gemilerde kürek çekme, gemilerde kılavuzluk yapma, gemi inşası, top ve benzeri malzemeleri gemilere indirme, bindirme ve taşıma işleriyle görevlendirilirdi.

Cerehorlar genellikle Hiristiyanlar arasından temin edilmekle birlikte, ${ }^{20}$ konumuzu teşkil eden döneme ait kayıtlar bunların hangi guruptan seçildiklerine pek atıfta bulunmamaktadır. ${ }^{21}$ Ancak bir kayıtta cerehorların Müslümanlar arasından da seçildiği açıkça görülmektedir. ${ }^{22} \mathrm{Ce}-$ rehorlara verilen ücret genellikle günlük değil, görevleri bitene kadar götürü usulü verilirdi ki, bu da ortalama olarak 1,5 ya da 2 esedi kuruş olarak değişmekteydi. ${ }^{23}$ Ancak ücretlerinin 3,5 ve 4 kuruş olarak verildiğini gösteren örnekler de mevcuttur. İncelediğimiz dönemde ücretin yevmiye bazında akçe olarak ödendiğini gösteren sadece bir örnek vardır ki, o da yevmiyenin 18 akçe olduğunu ortaya koymaktadır. ${ }^{24}$

Rusçuk ve çevresinde gemilerde görevlendirilmek üzere temin edilmiş cerehorlarla ilgili önemli bir husus, bunların büyük oranda kendi kazaları sınırlarında görev yapmalarıdır. Konuyla ilgili fermanlardan anlaşıldığına göre kadılar ve diğer görevliler, temin ettikleri cerehor-

1916 Ekim 1695 tarihli bir fermandan anlaşıldığına göre kadı ve diğer devlet görevlileri, gemilerle top taşınması için bölgelerinden cerehor temin etmiş ve bu işin takibiyle görevlendirilmiş olan Topçular Kethüdası Mustafa aracılığılla gemi reislerine cerehorları teslim etmişlerdir. $R$ 4, v.54b.

20 Rossitsa Gradeva, "War and Peace Along the Danube: Vidin at the End of the Seventeenth Century", Oriente Moderno, 20 (81), Nr.1, 2001, s.167.

21 İncelediğimiz dönemden kısa süre sonra, 1716 Habsburg seferinde, daha önce görevlendirilenlere ilave olarak Vidin'den 300 cerehor temin edilmiş, hizmetlerine karş1lık verilecek ücretlerin cizyelerine takas olunacağı belirtilmiştir. Cizye meselesinden dolayı cerehorların gayrimüslim oldukları anlaşılmaktadır. Hakan Karagöz, "Venedik (1716) ve Habsburg (1716-1717) Seferlerinde Vidin Şehrinin Askerî ve Lojistik Önemi”, Edebiyat Fakültesi Dergisi, Cilt 30, Sayı 2, Aralık 2013, s.104.

22 R 4 , v.118b.

23 II. Mustafa'nın I. Avusturya Seferi sonunda Rusçuk kazasının masraf bilançosunu gösteren deftere göre de cerehorlara verilen ücretler ortalama 1,5 ile 2 esedi kuruş arasında değişmektedir. Bkz. Mehmet Topal, "II. Mustafa'nın Avusturya Seferlerinde Rusçuk Şehri ve Limanının Önemi”, Türklük Araştırmaları Dergisi, S.20, İstanbul 2008, s.245.

$24 R$, v.98b, 118b, 119a, 121a. 
ları gemiler kendi kazalarına geldiklerinde hazır bulundurur ve gemi kaptanlarına ya da ilgili mübaşirlere teslim ederlerdi. ${ }^{25} \mathrm{Bu}$ durumda gemiler diğer kazalara ulaştığında bir önceki cerehorların görevi bitip, yeni kazadaki cerehorların görevlerinin başlamış olması gerekir. Öte yandan cerehorların kaza sınırlarından daha uzak bölgelere kadar görevlendirildiğine dair örnekler de vardır. ${ }^{26}$

\section{Rusçuk ve Çevresindeki Cerehorların Görevlendirildikleri Yerler}

Rusçuk şehri Tuna Nehri kenarında bulunduğundan, XVII. yüzyılın sonlarında çevreden temin edilen cerehorlar daha ziyade nehir yoluyla devlete ait malzemelerin, erzağın, esirler ve benzeri unsurların bir yerden başka bir yere nakli için gemilerde ve gemi inşa işinde çalıştırılırlardı. Bu duruma savaş zamanlarında daha sık rastlanırdı. Nitekim 1694 yılında II. Ahmed'in padişahlığ 1 döneminde Avusturya ile savaş devam etmekte, Osmanlı ordusu merkez olarak Belgrad'1 kullanmaktayd1. ${ }^{27}$ II. Ahmed'in vefat etmeden kısa süre önce 29 Ocak 1695 tarihinde Tuna Nehri kenarında bulunan kadılar ile iskele eminleri, kale zabitleri ve Eflak boyarlarına hitaben gönderdiği fermanda; Kili, İsakçı, Silistre, Rusçuk, Niğbolu ve Vidin iskelelerinde Belgrad'a nakledilmek üzere gemilere zahire yüklendiği ve bu gemilerde cerehorların çalıştığı beyan edilmektedir. ${ }^{28}$

25 Silistre ile Belgrad arasında bulunan kaza kadıları ile diğer görevlilere hitaben yazılan 9 Haziran 1695 tarihli bir fermanda zahire yüklü gemiler için "kazadan kazaya" cerehor temin edilmesi emredilmiştir. 16 Ekim 1695 tarihli başka bir fermanda ise her bir kazadaki görevlilere 55 tane cerehor temin etmeleri emredilmiştir. $R$ 4, v.35a, 36a, 54b.

2622 Nisan 1695 tarihinde Yergöğü ile Vidin arasındaki kadılara hitaben yazılan bir fermanda, Kırım Hanı Selim Giray Han Yergöğü’nden Vidin'e giderken gemide kürek çekmek için görevlendirilen cerehorlara ücretlerinin Vidin'de "zahire kâbızı" tarafından verileceği bildirilmiştir. $R$ 4, v.35a.

27 II. Ahmed dönemi için bkz. Mücteba İlgürel, “Ahmed II”, TDVİA, C.II, İstanbul 1989, s.33-34.

$28 R$ 4, v.37b. Benzer şekilde II. Mustafa dönemine ait 9 Haziran 1695 tarihli bir başka fermanda Silistre, Rusçuk ve Niğbolu iskelelerinde zahire yüklenerek Belgrad'a giden gemilere cerehor temin edilmesi Tuna Nehri boyunca Silistre ile Belgrad arasındaki kadı ve diğer görevlilere emredilmiştir. $R$ 4, v.36a. 12 Haziran 1695 'te bu defa Çardak, Silistre, Hırsova, Yergöğü, Rusçuk, Ziştovi, Niğbolu ve Vidin kadıları ile diğer görevlileri zikredilerek bu iskelelerde zahire yüklenen gemileri çekmeleri için yeterli miktarda cerehor temin etmeleri ve gemi reislerine teslim etmeleri, aksi takdirde kusurlu bulunup cezalandırılacakları ifade edilmiştir. $R 4$, v.37a. 
II. Ahmed'in ölümünden sonra tahta çıkan II. Mustafa döneminde de Avusturya ile savaşlar devam etmiştir. Bu savaşlarda Tuna Nehri yine yoğun bir şekilde kullanılmıştır. Bu nedenle Tuna Nehri'nde asker, askerî mühimmat ve ordu için zahire taşıyan gemiler oldukça önemli hale gelmiştir. I. Avusturya Seferi'nde Kırım Hanı Selim Giray Han da sefere çağrılmış, 22 Nisan 1695 tarihinde Yergöğü limanında kendisine 15 tane üstü açık gemi tahsis edilerek yeterli miktarda cerehor temin edilmesi emredilmiş, cerehor ücretlerinin eskiden belirlenmiş kurallar çerçevesinde Vidin'deki "zahire kâbızı" tarafından ödeneceği belirtilmiştir. ${ }^{29}$ Sonuç olarak bu gemilerde kürek çekmek için 7 Haziran 1695 tarihinde Rusçuk mahallelerinden cerehorlar temin edilmiştir. Mahalleler ve cerehor sayıları ile ilgili detaylar şu şekildedir:

Varoş-1 Tuna ve Orta: 22 cerehor, Mahalle-i Cami-i Cedid: 12 cerehor, Mahalle-i Cami-i Atik: 2 cerehor (bir tanesi gelmemiştir), Mahalle-i Kara Mustafa: 10 cerehor, Mahalle-i El-Hac Musa: 15 cerehor, Mahalle-i Fayik: 6 cerehor, Mahalle-i Mesih: 3 cerehor, Mahalle-i Mahmud Voyvoda: 3 cerehor, Mahalle-i Bacanak: 3 cerehor, Mahalle-i Ermeniyan: 10 cerehor, Mahalle-i Kuyumcu: 2 cerehor, Mahalle-i Arık Ramazan: 6 cerehor. Ayrıca Rumlardan tüfenkciyan ve kürekçiyan olarak 12 cerehor, hanlarda sakin Acemlerden 12 cerehor temin edilmiştir. Başlangıçta Selim Giray için 15 gemi tahsis edileceği belirtilmekle birlikte tahsis edilen gemi sayısının 7 olduğu görülmektedir. Toplam cerehor sayısı ise 118 olmuştur. ${ }^{30}$

Bundan kısa süre sonra, 13 Haziran 1695 tarihli bir hükümden anlaşıldığına göre Vidin'de top yüklenen 5 tane gemi Ziştovi iskelesine ulaştığında, Rusçuk mahallelerinden bir miktar cerehor bu gemiler için görevlendirilmiştir. Buna göre Cami-i Cedid Mahallesi’nden 5, El-Hac Musa Mahallesi'nden 5, Kara Mustafa Mahallesi'nden 3,

$29 R$ 4, v.35a. Cerehor sayıları muhtemelen geminin büyüklüğüne, taşıdıkları kimselerin önemine, taşıdıkları malzemenin miktarına vs. göre değişmekteydi. İncelediğimiz döneminde cerehor sayılarının hangi kritere göre belirlendiğini gösteren kayıtlar mevcut olmamakla birlikte 1739 Belgrad seferinde zahire nakledilirken her 1000 kile zahire için 3 cerehora ihtiyaç duyulduğu belirtilmiştir. Hakan Karagöz, 1737-1739 Osmanll-Avusturya Harbi ve Belgrad'ın Geri Alınması, Süleyman Demirel Üniversitesi Sosyal Bilimler Enstitüsü, Basılmamış Doktora Tezi, Isparta 2008, s.77.

$30 R 4$, v.119a. 
Fayik Mahallesi'nden 2, Arık Ramazan Mahallesi'nden 2, Mahmud Voyvoda Mahallesi'nden 1, Mesih Voyvoda Mahallesi'nden 1, Cami-i Atik Mahallesi'nden 1, Bacanak Mahallesi'nden 1, Ermeniyan Mahallesi'nden 1, Kuyumcu Mahallesi'nden 1, Tuna Mahallesi'nden 5 ve Orta Mahallesi'nden yine 5 cerehor bu gemiler için görevlendirilmiştir. Böylece Rusçuk mahallelerinden bu iş için temin edilen cerehor sayısı 33 olmuştur. Ayrıca hanlarda ikamet eden Acemlerden 5, kalpakçılardan 3 ve kömürcülerden 4 cerehor olmak üzere 12 kişi daha görevlendirilmiştir. Buna ilaveten Emin Abbas Ağa 4 gemiye 4 kılavuz cerehor vermiştir. ${ }^{31}$

Aynı dönemlere ait bir başka hükümde, Kapucubaşı Ali Ağa, Mirza Ağa'nın gemisiyle Silistre'ye giderken beraberinde giden kul kayığ1na cerehorlar görevlendirilmiştir. ${ }^{32}$ Sebebi belirtilmemekle birlikte cerehorların ayrı bir gemide görevlendirilmeleri ilginçtir. Görevlerinin, Kapucubaşı Ali Ağa'nın bindiği gemiye bir başka gemiyle kılavuzluk yapmak ve gerektiği yerlerde gemiyi iple çekerek girdaplardan korumak olduğu düşünülebilir. ${ }^{33}$

II. Mustafa 10 Ekim 1695 tarihinde I. Avusturya Seferi'nden başarı ile dönerken, Rusçuk'tan üstü açık gemiler temin edilmiş ve bu gemiler için yine Rusçuk mahallelerinden cerehorlar görevlendirilmiştir. Buna göre Bacanak Mahallesi'nden 1, Cami-i Cedid Mahallesi'nden 4, Fayik Mahallesi'nden 2, Arık Ramazan Mahallesi'nden 2, Tuna ve Orta mahallelerinden 8, Mahmud Voyvoda Mahallesi'nden 1, Cami-i Atik Mahallesi'nden 1, Kuyumcu Mahallesi'nden 1, Ermeni Mahallesi'nden 1 ve Mesih Mahallesi'nden 1 olmak üzere toplam 22 cerehor belirlen-

$31 R 4$, v.119a.

$32 R 4$, v.119a.

33 Özellikle Belgrad ile Vidin arasında yer alan Turnu Severin ve Ostrova bölgelerinde bulunan girdaplardan Tahtalı, İnlik ve Demirkapı girdapları oldukça tehlikeliydi. Buralarda gemiler kıyıdan iplerle bağlanır ve cerehorlar aracılığıyla yönlendirilirdi. M. Emre Kılıçaslan, “XVIII. Yüzyılda Tuna Demirkapısı ve Girdaplar İdaresi”, Karadeniz Araştırmaları, Sa.25, 2010, s.68-69. Bekir Gökpınar da, Vidin'den sonra gelen girdaplar bölgesinde gemilerin normal seyrinin mümkün olmadığını, mutlaka cerehorlar yardımıyla geçirilmesi gerektiğini belirtmektedir. Bekir Gökpınar, "Osmanlı Avusturya Savaşlarında Tuna Nehri'nden Yapılan Sevkiyatta Yaşanan Problemler (1716-1718)”, Balkan Tarihi, Ed. Zafer Gölen, Abidin Temizer, C.II, Ankara 2006, s.300-301. 
miştir. Cerehor ücreti olarak El-Hac Musa Mahallesi'nden 14 esedi kuruş, Kara Mustafa Mahallesi'nden 9 esedi kuruş alınmakla birlikte bu iki mahalleden cerehor verilip verilmediği hükümde belirtilmemektedir. ${ }^{34}$

Bahsi geçen savaş dönemlerinde gemilerin yeterli gelmediği durumlarda yeni gemi inşası için fermanların sadır olduğu görülmektedir. Nitekim II. Mustafa'nın I. Avusturya seferinin sonuna denk gelen dönemde, ${ }^{35} 4$ Ekim 1695 tarihli bir fermanda Belgrad'a zahire taşınması için yeni gemilere ihtiyaç duyulduğu ifade edilmiştir. Bu nedenle eski Tuna Kapudânı Ali'nin kethüdası olan İbrahim adlı şahıs gemi inşa etme konusunda uzman olduğundan bu iş için görevlendirilmiştir. Buna göre ertesi yılın ilkbaharına kadar Yergöğü'nde 15 tane Borazan gemisi inşa edilecek, bu gemilerin inşası için neccar, kalafatçı ve cerehor gibi ameleler temin edilecek, bunlara Tuna sahillerinde eskiden beri bu tür işlerde verilegelen ücretler ödenecektir. ${ }^{36}$

Yine aynı dönemlerde; Niğbolu'dan İstanbul'a Tuna Nehri üzerinden top nakledilmesiyle ilgili 16 Ekim 1695 tarihli bir fermana göre nakil işleminde 9 tane gemi kullanılmış ve bu gemilerde çalıştırılmak üzere 55 cerehor temin edilmiştir. Cerehorların sayıları ve görevlendirildikleri gemiler şu şekildedir: Silistreli İbrahim Reis gemisi için 10 nefer, Rusçuklu Hacı Mehmed gemisi için 9 nefer, Rusçuklu Hacı Şahin gemisi için 8 nefer, İbrailli İsmail gemisi için 8 nefer, Rusçuklu Bekir Reis gemisi için 4 nefer, Rusçuklu Ramazan Reis gemisi için 4 nefer, Niğbolulu Ağa oğlu gemisi için 4 nefer, Niğbolulu başka bir reisin gemisi için 4 nefer ve Hırsovalı Mehmed Reis gemisi için 4 nefer. 17 Ekim 1695'te kaleme alınan başka bir fermanda, yine Niğbolu'dan Tuna Nehri yoluyla bir miktar yeniçerinin muhafazası altında İstanbul'a gönderilen miri esirler için iki gemi temin edildiği, bu gemilere her kazadan yeterli miktarda cerehor ayarlamaları gerektiği Tuna kıyısında bulunan kazaların kadıları başta olmak üzere devlet görevlilerine emredilmiştir. Sonuç olarak bu gemilere ücretleri El-Hac Mustafa Ağa

\footnotetext{
$34 R$, v.119a.
}

35 II. Mustafa'nın Avusturya seferleriyle ilgili olarak bkz. Abdülkadir Özcan, "Mustafa II", TDVIA, C. 31, İstanbul 2006, s.276-277.

$36 R$, v.57a. 
tarafindan ödenmek üzere 12 cerehor ayarlanmıştır. Top ve esir taşıyan bu gemiler nehirde yol aldıklarından biraz küçük olup, görevleri nehrin Karadeniz'e çıkışında sona ermekte, burada deniz gemilerine aktarma yapilmaktayd1. ${ }^{37}$

Yukarıda verilen örnekte olduğu gibi yine 16 Ekim 1695 tarihine ait başka bir fermanda; II. Mustafa'nın zaferle sonuçlanan I. Avusturya seferinde ganimet olarak epeyce top elde edildiği, bunların 7 tane üstü açık ve Tuna gemileri adı verilen nehir gemileriyle Rusçuk'a ulaştırıldığı ifade edilmektedir. Bu gemilerde çalıştırılmak üzere topçular kethüdası Mustafa Ağa ve Çorbacı Halil Ağa'nın gözetimi altında toplam 81 cerehor görevlendirilmiştir. Gemiler ve cerehorlar ile ilgili detaylar şu şekildedir:

Birinci top yüklü geminin kaptanı Rusçuklu Ramazan Reis olup gemisinde Baba Hızır, Hasan Beşe, Hüseyin Beşe, Ömer Beşe ve dümenci olarak 5 adet cerehor görev yapmıştır.

İkinci top yüklü geminin kaptanı Silistreli İbrahim Reis olup gemisinde Topçu Sefer, Fıçıcı İbrahim, Mustafa bin Abdullah, Mehmed bin Bekir, Veli bin Arslan, Hasan bin Mehmed, Abdülkadir bin Ahmed, Ahmed bin Mustafa, Osman bin Mustafa ve Ahmed bin Ömer olmak üzere toplam 10 adet cerehor görev yapmıştır.

Üçüncü top yüklü geminin kaptanı Hırsovalı Mehmed Ağa olup gemisinde Hasan bin Osman, Murad bin Mehmed, Hasan bin Mahmud ve İbrahim bin Osman olmak üzere toplam 4 adet cerehor görev yapmıştır.

Dördüncü top yüklü geminin kaptanı Hacı Mehmed Reis olup gemisinde toplam 9 adet cerehor görev yapmıştır.

Beşinci top yüklü geminin kaptanı Niğbolulu İbrahim Reis olup gemisinde toplam 4 adet cerehor görev yapmıştır.

Altıncı top yüklü geminin kaptanı Niğbolulu Ağa oğlu olup gemisinde toplam 5 adet cerehor görev yapmıştır.

Yedinci top yüklü geminin kaptanı Rusçuklu Bekir Reis olup gemisinde toplam 4 adet cerehor görev yapmıştır.

$37 R 4$, v. 54b, $118 \mathrm{~b}$. 
Bu gemilerdeki cerehor sayısı toplam 41 olup, bunlara Acemlerden 10, Rumlardan 10, varoştan 5, kömürcülerden 3 kişi olmak üzere 28 cerehor daha ilave edilmiş ve sayı 69'a yükselmiştir. Ayrıca El-Hac Mustafa Ağa'nın verdiği 18 esedi kuruş ile 12 cerehor daha temin edilerek toplam cerehor sayısı 81 'e ulaşmıştır. ${ }^{38}$

21 Ekim 1695 tarihinde ise Belgrad'dan İstanbul'a otağ-1 hümayun ve mehterhane-i âmire mühimmatı taşıyan gemiye, Silistre'ye ulaşıncaya kadar görevli olmak üzere 20 tane cerehor temin edilmiştir. Benzer şekilde aynı tarihte yine Belgrad tarafından İstanbul'a giden ve içinde tüfenkçi, yeniçeri eşyaları ve dergah-1 ali cebecilerinin hastaları ile yaralılarını taşıyan gemiye cebeci çorbacısı aracılığıyla 10 tane cerehor ayarlanmıştır. ${ }^{39}$

Mehterhane-i âmire mühimmatı taşıyan gemiler ve cerehorlar ile ilgili bir başka hüküm 21 Ekim tarihli bir önceki örnek ile yine aynı sayfada yer almakta, fakat farklı bilgiler içermektedir. Buna göre yine Belgrad tarafindan gelip Tuna gemileri ile İstanbul'a giden mehterhane-i âmire mühimmatı taşıyan 7 ayrı gemiye Rusçuk'un mahallelerinden değişik sayılarda cerehorlar temin edilmiştir. Mahallelerin verdiği cerehorların dağılımı ile ilgili detaylar şu şekildedir:

Mahalle-i Kara Mustafa: 6 cerehor, Mahalle-i Arık Ramazan: 4 cerehor, Mahalle-i Kuyumcu: 2 cerehor, Mahalle-i Cami-i Cedid: 8 cerehor, Mahalle-i Mahmud Voyvoda: 2 cerehor, Mahalle-i Mesih Voyvoda: 2 cerehor, Mahalle-i Fayik: 4 cerehor, Mahalle-i Ermeniyan. 2 cerehor, Mahalle-i Cami-i Atik. 2 cerehor, Mahalle-i Bacanak: 2 cerehor, Mahalle-i Tuna ve Orta: 7 cerehor, Mahalle-i El-Hac Musa: 8 cerehor.

Rusçuk mahallelerinden temin edilen bu cerehorların gemilere dağıll$\mathrm{m}$ ise aşağıdaki gibidir:

Sefine-i Mehmed Reis: 6 cerehor, sefine-i Hüseyin Beşe: 5 cerehor, sefine-i Bayram Beşe: 5 cerehor, sefine-i Ali Reis: 3 cerehor, Sefine-i Karagöz Mustafa: 5 cerehor, sefine-i Ramazan Reis: 5 cerehor, sefine-i Yusuf bin Hüseyin Çelebi: 5 cerehor.

$38 R$, v. 118 b.

$39 R$, v.118b. 
$\mathrm{Bu}$ gemilere toplam 34 tane cerehorun dağıtımı yapılmış, Tuna ve Orta Mahallesi ile El-Hac Musa Mahallesi'nden temin edilen 15 kişi fazla geldiğinden gemilerde görevlendirilmemiştir. ${ }^{40}$

1696 yılı başlarına gelindiğinde, II. Mustafa'nın II. Avusturya seferinin hemen öncesinde, Silistre ve Niğbolu sancaklarında avarız vergileri karşı1lığında arpa veren kazalardan alınan 29.000 kile arpanın Silistre iskelesine ve 73.992,5 kile arpanın Rusçuk iskelesine nakledilmesinin emredildiği görülmektedir. Ordunun ihtiyacı için Belgrad'a gönderilmek üzere bu limanlarda gemilere yüklenen arpanın nakledilmesi işinde de yeterli sayıda cerehor görevlendirilmiştir. ${ }^{41}$

Hicri 1108 senesinde (1696-1697) Tuna Nehri’nde doğu ve batı istikametinde bir görev için seyahat eden ulaklara Emin İbrahim Ağa'nın 40 tane cerehor temin ettiği görülmektedir. Bu cerehorların hangi durumlarda ne kadar verildiğiyle ilgili bilgiler aşağıdaki gibidir: Kırım Hanı Selim Giray'ın oğlu Şahbaz Giray Sultan'ın bazı hayvanlarının Silistre tarafina nakli için 7, Silistre'ye top taşıyan gemiler için 5, Silistre'ye yeniçeri taşıyan gemiler için 4, Silistre'ye giden Kapıcıbaşı Ali Ağa'ya eşlik etmeleri için 8, İbrahim Paşa'nın adamları için 4, Silistre Valisi Hasan Paşa'nın adamları için 4, yine Hasan Paşa'nın yaralı tatarı Silistre'ye giderken eşlik etmeleri için 4 ve Kapudan Mehmed Paşa Ziştovi İskelesine giderken menzil kayığına 4 cerehor verilmiştir ki, Emin İbrahim Ağa tarafindan bu işler için toplamda 40 cerehor görevlendirilmiştir. ${ }^{42}$

Savaş dönemlerinde cerehor kullanımı yoğun olmakla birlikte barış dönemlerinde de çeşitli görevler için yine cerehorlara müracaat edilirdi. Örneğin Tuna Nehri üzerinde seyahat eden elçilik heyetlerine cerehorlar tahsis edilmesi olağan bir durumdu. Nitekim, incelediğimiz dönemin hemen akabinde 1699 Karlofça Antlaşması öncesinde Osman11 Devleti ile Habsburglar arasında aracılık yapmak için Viyana'dan İstanbul'a seyahat eden İngiliz ve Alman elçilerine 200 cerehor tahsis edildiği görülmektedir. ${ }^{43}$

$40 R$, v. 118 b.

$41 R 4$, v.98b. Cerehorlar zahire yüklü gemilerde görevlendirildiği gibi çeşitli erzak taşıyan gemilerde de görevlendirilirlerdi. $R$ 4, v.119a.

$42 R 4$, v.121a.

43 Gradeva, a.g.m., s.169. 


\section{Rusçuk ve Çevresindeki Cerehorların Firar Olayları}

Her ne kadar ücretleri ödeniyorsa da, cerehorlar geçici olarak bir devlet işinde görevlendirildiklerinde firsat buldukları takdirde kaçmayı denerlerdi. Aldıkları ücretlerin kendilerini tatmin etmemesi yanında, işlerinin kürek çekmek, gemilere yükleme yapmak ve gemi inşa etmek gibi ağır sayılabilecek işler olması da muhtemelen cerehorların firarlarında etkili olmuştur. ${ }^{44}$

1695 tarihinde Kili tarafından Tuna yoluyla gelip Belgrad'a zahire taş1yan gemilerde görevli olan cerehorlar Belgrad'da ücretlerini almışlar, ancak dönüş yolunda bunlardan bir kısmı firar etmişlerdir. Bunun üzerine II. Ahmed tarafindan Tuna kıyısındaki kadılara, iskele eminlerine, kale zabitlerine ve Eflak boyarlarına hitaben bir ferman gönderilmiş, bu firarilerin bulunması için gayret etmeleri, bulunduklarında kendilerine verilen ücretlerin geri alınması ya da aynı gemilerde çalıştırılmaları emredilmiştir. ${ }^{45}$

II. Mustafa dönemine ait 9 Haziran 1695 tarihli bir fermanda Silistre, Rusçuk ve Niğbolu iskelelerinde zahire yüklenerek Belgrad'a giden gemilerde görevli cerehorlardan bazıları yolda firar ettiğinden, bunların yerine ücretleri devlet tarafından verilmek üzere derhal yenilerinin tedarik edilmesi emredilmiştir. Asker için zahire olayı önemli olduğundan görevlilerin bu konuda ihmali olursa şiddetli bir şeklide cezaland1rılacakları da ihtar edilmiştir. ${ }^{46}$

18 Ekim 1695 tarihli yine II. Mustafa dönemine ait iki ayrı fermanda ise Niğbolu'dan Tuna Nehri yoluyla Karadeniz'e kadar nehir gemileriyle, oradan da deniz gemileriyle İstanbul'a nakli emredilen otağ-1

44 İncelediğimiz dönemden yaklaşık on yıl önce, 1685 senesinde Şehirköy kazası ahalisi durumlarının iyi olmadığından dem vurarak Tahtalı girdabında çalışmak üzere kendilerinden talep edilen 150 nefer cerehoru vermeğe güçlerinin olmadığını beyan etmişlerdir. Bu konuda ısrar edilirse firar etmelerinin kaçınılmaz olacağı anlaşıldığından ricaları kabul edilerek ilgili senede kendilerinden cerehor talep edilmemiştir. Ahmet Kıriş, Hicri 1096 (1684-1685) Yılına Dair Bir Münşeat Mecmuası ve Değerlendirilmesi, Fatih Sultan Mehmet Vakıf Üniversitesi Sosyal Bilimler Enstitüsü, Basılmamış Yüksek Lisans Tezi, İstanbul 2017, s.61.

$45 R$, v.37b.

$46 R$, v.36a. 
hümayun ve mehterhane mühimmatı taşıyan gemilerdeki cerehorların firar etmeleri halinde, kadı ve diğer görevlilerin bu gemilere yeni cerehorlar tedarik etmeleri emredilmiştir. Bu konuda titiz davranmaları, gemilerin tamire muhtaç yerleri varsa tamir ettirmeleri ve kış gelmeden gemilerin İstanbul'a ulaşması noktasında gayret sarf etmemeleri durumunda cezalandırılacakları ayrıca ilave edilmiştir. ${ }^{47}$

\section{Rusçuk ve Çevresindeki Cerehorların Aldıkları Ücretler}

Tuna Nehri'nin bazı yerleri yelken açmaya uygun olsa da, özellikle yukarı gidişler için cerehor kullanılırdı. 1713 yılı ölçeğinde, Vidin-Rusçuk arasında 2.000'den fazla Hıristiyan delikanlı dümenci ve kürekçi olarak cerehor hizmeti görmek suretiyle geçimini sağlardı. Mahir Aydın hizmet satın alımı olarak gerçekleşen bu görevlerde, ekmek parasının her gün, emeğin karşıllı̆ı olan ücretin ise işin bitiminde verildiğini belirtmektedir. ${ }^{48}$

29 Ocak 1695 tarihli bir fermandan anlaşıldığına göre, Kili, İsakçı, Silistre istikametinden gelerek Belgrad'a zahire taşıyan mîrî gemilerde görevli cerehorlara Belgrad'a vardıklarında ücretleri ödenmiş, ücret ödemek için geri dönüşleri beklenmemiştir. ${ }^{49}$ Benzer şekilde $22 \mathrm{Ni}$ san 1695 tarihinde Kırım Hanı Selim Giray’1 Yergöğü’nden Vidin'e götüren gemilerde kürek çekmek için görevlendirilen cerehorların ücretlerinin Vidin'de ödeneceği belirtilmiştir. ${ }^{50} 9$ Haziran 1695 tarihli başka bir fermanda ise Silistre'den Belgrad'a zahire taşıan gemilerde görevli cerehorlardan firar edenlerin yerine yeni temin edilecek olan cerehorların ücretlerinin devlet tarafından ödeneceği ifade edilmiştir. ${ }^{51}$ Bundan üç gün sonrasına ait bir fermanda yine zahire gemilerinde kürek çekmek için görevlendirilen cerehorların ücretlerinin mübâya'a mübaşirleri tarafindan eskiden olduğu gibi ödeneceği dile getirilmiştir. $^{52} 4$ Ekim 1695 tarihli başka bir fermana göre ise Yergöğü'nde inşa

$47 R$ 4, v.54b; v. 55a-55b.

48 Mahir Aydın, Vidin Kalesi: Tuna Boyu'ndaki İnci, İstanbul 2015, s.25-26.

$49 R$, v.37b.

$50 R 4$, v.35a.

$51 R 4$, v.36a.

$52 R 4$, v.37a. 
edilecek 15 tane Borazan gemisi için cerehorlar görevlendirilmiş ve bunlara Tuna sahillerinde eskiden beri bu tür işlerde ödenen ücretler ödenmiştir. ${ }^{53}$ Ancak beş örnekte de cerehorlara ne kadar ücret ödendiği kayıtlarda yer almamaktadır.

II. Mustafa'nın I. Avusturya Seferi'nde Kırım Hanı Selim Giray Han sefere davet edilmiş, kendisine tahsis edilen 15 tane üstü açık gemi için 7 Haziran 1695 tarihinde Rusçuk mahallelerinden 117 tane cerehor görevlendirilmiştir. Bu cerehorlara 2 esedi kuruştan ödeme yapılmıştır. ${ }^{54}$ Bunun gibi 13 Haziran 1695 tarihinde Vidin'den top yüklenmiş olarak Ziştovi'ye ulaşan 5 tane gemi için görevlendirilen Rusçuklu 49 cerehorun ücretleri de yine 2 esedi kuruştan ödenmiştir. Bu ücretin büyük bir kısmı Voyvoda Hasan Ağa ve Abbas Çelebi tarafından verilmiştir. ${ }^{55}$

Aynı dönemlerde, Kapucubaşı Ali Ağa'nın Silistre'ye giderken bindiği gemiye eşlik eden diğer bir gemide görevlendirilen cerehorlara kadı tarafından 7,5 esedi kuruş verildiği kaydedilmektedir. ${ }^{56}$ Burada cerehor sayısı belirtilmemekle birlikte diğer örnekler dikkate alındığında kişi başı ortalama 1,5 kuruş baz alınarak toplam 5 cerehora bu paranın verildiği düşünülebilir.

II. Mustafa başarılı geçen I. Avusturya Seferi'nden dönerken üstü açık gemilerle birlikte Rusçuk'taki mahallelerden ücretleri belirlenerek bir miktar cerehor görevlendirildiği dikkat çekmektedir. Buna göre mahallelerin cerehorlar için ödediği ücretler esedi kuruş olarak şu şekildedir: Bacanak Mahallesi 4, Cami-i Cedid Mahallesi 10, Fayik Mahallesi 7, Arık Ramazan Mahallesi 7, Tuna ve Orta mahalleleri 30, Mahmud Voyvoda Mahallesi 3,5, Cami-i Atik Mahallesi 3,5, Kuyumcu Mahallesi 4, Ermeni Mahallesi 4, Mesih Mahallesi 4, El-Hac Musa Mahallesi 14 ve Kara Mustafa Mahallesi 9. Mahallelerin cerehorlar için ödediği toplam rakam 105 esedi kuruştur. Bacanak Mahallesi 1 cerehor için 4 esedi kuruş öderken, Fayik Mahallesi 1 cerehor için 3,5 kuruş ödemiş; Cami-i Cedid, Tuna ve Orta mahalleleri ise 3,5-4 esedi kuruş arasında

$53 R$, v.57a.

$54 R$, v.119a.

$55 R$, v.119a.

$56 R 4$, v.119a.

Akademik Incelemeler Dergisi, Cilt: 13, Sayı: 1 (Nisan 2018) 
bir ödeme yapmışlardır. ${ }^{57}$ Diğer örneklere bakıldığında cerehorlara genellikle 1,5 ya da 2 esedi kuruş ödeme yapılırken, burada mahallelerin ödediği miktar daha yüksektir. Cerehorların bu defa bizzat padişahın kafilesinde görev yapacak olmalarının bunda etkili olduğu düşünülebilir.

16 Ekim 1695 tarihli bir fermana göre, II. Mustafa'nın zaferle sonuçlanan I. Avusturya seferinde ganimet olarak elde edilen toplar Rusçuk'a nakledildiğinde, top taşıyan 7 tane gemide çalıştırılmak üzere topçular kethüdası Mustafa Ağa ve çorbac1 Halil Ağa'nın gözetimi altında her birine 1,5 kuruştan toplam 121,5 esedi kuruş ücret ödenmek üzere toplam 81 cerehor görevlendirilmiştir. ${ }^{58}$

Benzer şekilde, 17 Ekim 1695 tarihinde Niğbolu' dan Tuna Nehri yoluyla yeniçerilerin muhafazası altında İstanbul'a gönderilen ve Rusçuk'a ulaşan mîrî esirler için iki gemiye 12 tane cerehor temin edilmiş, ücretleri El-Hac Mustafa Ağa tarafından 1,5 esedi kuruştan toplam 18 esedi kuruş olarak ödenmiştir..$^{59}$

21 Ekim 1695 tarihinde, bu defa Belgrad'dan İstanbul'a bir gemi ile otağ-1 hümayun ve mehterhane-i âmire mühimmatı taşındığı dikkat çekmektedir. Bu gemiye Silistre'ye kadar görev yapmaları için 20 cerehor temin edilmiş ve kendilerine ücretleri 1,5 esedi kuruştan olmak üzere serdar Abdi Ağa, voyvoda Hasan Ağa ve El-Hac Mustafa Ağa tarafından ödenmiştir. Benzer şekilde yine Belgrad'dan İstanbul'a mehterhane-i âmire mühimmatı taşıyan 7 tane gemiye Rusçuk mahallelerinden temin edilen 34 cerehor için 1,5 kuruştan toplam 51 esedi kuruş ödeme yapılmıştır. ${ }^{60}$ Aynı tarihte yine Belgrad tarafindan gelen fakat bu defa tüfenkçi, yeniçeri eşyaları ve cebeci hastaları ile yaralılarını taşıyan gemiye cebeci çorbacısı marifetiyle 10 cerehor ayarlanmış ve ücretleri yine 1,5 esedi kuruştan 15 esedi kuruş olarak ödenmiştir. ${ }^{61}$

$57 R 4$, v.119a.

$58 R 4$, v. 118 b.

$59 R 4$, v.118b.

$60 R 4$, v. 118 b.

61 Silistre mütesellimi aynı tarihte gemi ile yolculuk yaparken yanına ücretleri yine 1,5 esedi kuruştan 4 tane cerehor temin edilmiş ve bunlara toplam 6 esedi kuruş ödeme 
Yine bu dönemlerde, yani II. Mustafa'nın I. Avusturya Seferi dönüşünde, firkate adı verilen gemilerde kürek çekmeleri için eski Rusçuk voyvodası Hasan Ağa 95 cerehor temin etmiş ve bunlara 129 esedi kuruş ödeme yapmıştır. ${ }^{62}$ Diğer örneklerden farklı olarak burada kişi başına 1,3 esedi kuruş düşmektedir.

II. Mustafa'nın II. Avusturya seferi öncesine denk gelen 1696 yılı başlarına ait bir fermanda, avarız vergisi karşılı̆g 1 temin edilen arpalardan belirli miktarda Silistre ve Rusçuk limanlarına sevk edilmesi ve burada görevlendirilecek olan cerehorlarla gemilere yüklenerek ordunun beslenmesi amacıyla Belgrad'a gönderilmesi emredilmiştir. Bu iş için görevlendirilecek cerehorlara "arpa kulu" tarafindan yevmiye 18 akçe verileceği belirtilmiştir. ${ }^{63}$ Cerehor ücretleri görüldüğü kadarıyla götürü usulü verilirken, bu örnekte yevmiye olarak verilmesi dikkat çekmektedir. $^{64}$

\section{Sonuç}

1694-1698 yı1ları arasında Rusçuk şehrinde karşımıza çıkan cerehorlar, geçici olarak ücret karşılığı gemilerde kürek çekme ve gemi inşa etme faaliyetlerinde kullanılmışlardır. İncelenen dönem Avusturya ile yapılan savaşlara denk geldiğinden, bunlar daha ziyade Tuna Nehri boyunca zahire, devlete ait malzeme, top, erzak, esir, hasta, yaralı ve

yapılmıştır. $R 4$, v.118b.

$62 R 4$, v.119b. Bu örnekte cerehor sayıs1 950 gibi yazılmıştır. Ancak cerehorlara verilen ücret 129 esedi kuruş olarak belirtildiğinden cerehor sayısı bu ücrete oranla tutarsız görülmektedir. Zira bu durumda, diğer örnekler göze alındığında, 950 cerehor için 1,5 ya da 2 esedi kuruştan 1425 ya da 1900 kuruş civarında bir ödeme yapılması gerekirdi. Oysa örnekte 129 kuruş ödendiği ifade edilmektedir. Bu nedenle cerehor sayısının 950 yerine 95 olabileceği düşünülebilir.

$63 R 4$, v.98b.

641698 yılında başka bir yerde ancak yine Tuna Nehri kıyısında cerehor ücretinin saat başına verildiğine dair örnekler de vardır. Nitekim 27 Nisan 1698 tarihinde İsmail Geçidi menzilcisine gönderilen bir emirde ulaklardan tuttukları cerehorlar için saat başına onar akçe alması gerektiği belirtilmiştir. Sema Altunan, "XVIII. yy'da Silistre Eyaletinde Haberleşme Ağı: Rumeli Sağ Kol Menzilleri”, OTAM, S.18, Ankara 2005, s.14. Öte yandan yaklaşık 80 sene sonra, 1778 y1lında, Akkirman Kalesi inşaatında çalıştırılan cerehorlara verilen yevmiyenin pek değişmediği, bunlara günlük 20 akçe verildiği dikkat çekmektedir. Oya Şenyurt, "Geç Osmanlı İnşaat Ortamında "Bina Eminliğiı", METU JFA, 25:2, 2008, s.154. 
benzeri unsurların naklinde, indirme ve bindirme faaliyetlerinde görev almışlardır. Bunun yanında gemi inşa faaliyetleri ile girdap olan bölgelerde gemilerin kolayca geçirilmesinde de kendilerinden yararlanılmıştır. Kadı ve diğer devlet görevlileri tarafından temin edilen cerehorlar gemi reislerine ya da ilgili mübaşirlere teslim edilmiş, ücretleri daha ziyade götürü usulü ortalama 2 esedi kuruştan ödenmiştir. Ücretleri devlet tarafindan ödenmekle birlikte zaman zaman ileri gelen kimseler de ödemelere katkı sağlamışlardır. Örneklere bakıldığında Rusçuk'taki mahallelerden değişik sayılarda cerehor temin edildiği görülmektedir. Cerehor temininde gönüllülük esas olmakla birlikte, devletin bu görevi yapacak insanlara ihtiyacı olduğundan gerektiğinde zorla cerehor temin edilme yoluna da gidilmiştir. Rusçuk’taki cerehorların gayrimüslimler ve Müslümanlar arasından seçilen ve ücretle çalışan amele gurupları olduğunu söylemek mümkündür. Sonuç olarak ilgili dönemde Avusturya ile savaşlar söz konusu olduğundan Rusçuk ve çevresinden görevlendirilen cerehorlar Osmanlı Devleti’ne büyük katkı sağlamıştır. 


\section{Kaynakça}

\section{Yayınlanmış Arşiv Belgeleri}

Bosna-Hersek İle İlgili Arşiv Belgeleri (1516 - 1919), Başbakanlık Devlet Arşivleri

Genel Müdürlüğü, Osmanlı Arşivi Daire Bşk., Yayın No: 7, Ankara 1992.

7 Numaralı Mühimme Defteri (975-976/1567-1569), II, Başbakanlık Devlet Arşivleri

Genel Müdürlüğü, Osmanlı Arşivi Daire Bşk., Yayın Nu: 37, Ankara 1999.

\section{Yayınlanmamış Arşiv Belgeleri}

Rusçuk Şer'iyye Sicili (R), Nr. 4, varak 35a, 36a, 37a, 37b, 54b, 55a, 55b, 57a, 98b, 118b, 119a, 119b, 121a.

\section{Basılı Kaynaklar}

Aktepe, Münir. "Çandarlı Ali Paşa”, TDVIAA, C.8, İstanbul 1993, ss.211-212.

Altunan, Sema. "XVIII. yy'da Silistre Eyaletinde Haberleşme Ağı: Rumeli Sağ Kol Menzilleri”, OTAM, S.18, Ankara 2005, ss.1-20.

Aydın, Mahir. Vidin Kalesi: Tuna Boyu'ndaki İnci, İstanbul 2015.

Demirtaş, Mehmet. "XVI. Yüzyılda Meydana Gelen Tabii Afetlerin İstanbul'un Sosyal ve Ekonomik Hayatına Etkilerine Dair Bazı Misaller", Atatürk Üniversitesi Sosyal Bilimler Enstitüsü Dergisi, Cilt 4, Say1 2, 2004, ss.37-50.

Erdoğan, Meryem Kaçan. II. Viyana Muhasarası, Marmara Üniversitesi Sosyal Bilimler Enstitüsü Basılmamış Doktora Tezi, İstanbul 2001.

Fodor, Pál. "The Way of a Seljuq Institution to Hungary: The Cerehor", Acta Orientalia, Vol.38, No.3, 1984, ss.367-389.

Gökpınar, Bekir. “Osmanlı Avusturya Savaşlarında Tuna Nehri'nden Yapılan Sevkiyatta Yaşanan Problemler (1716-1718)", Balkan Tarihi, Ed. Zafer Gölen, Abidin Temizer, C.II, Ankara 2006, ss.297-312.

Göksu, Erkan. Türkiye Selçuklularında Ordu, Gazi Üniversitesi Sosyal Bilimler Enstitüsü, Basılmamış Doktora Tezi, Ankara 2008. 
Gradeva, Rossitsa. "War and Peace Along the Danube: Vidin at the End of the Seventeenth Century", Oriente Moderno, 20 (81), Nr.1, 2001, ss. 149-175.

İlgürel, Mücteba. “Ahmed II”, TDVİA, C.2, İstanbul 1989, ss.33-34.

Karagöz, Hakan. 1737-1739 Osmanl-Avusturya Harbi ve Belgrad'ın Geri Alınması, Süleyman Demirel Üniversitesi Sosyal Bilimler Enstitüsü, Basılmamış Doktora Tezi, Isparta 2008.

Karagöz, Hakan. "Venedik (1716) ve Habsburg (1716-1717) Seferlerinde Vidin Şehrinin Askerî ve Lojistik Önemi”, Hacettepe Üniversitesi Edebiyat Fakültesi Dergisi, Cilt 30, Sayı 2, Aralık 2013, ss.83-116.

Kılıçaslan, M. Emre. "XVIII. Yüzyılda Tuna Demirkapısı ve Girdaplar İdaresi”, Karadeniz Araştırmaları, Sa.25, 2010, ss.59-76.

Kıriş, Ahmet. Hicri 1096 (1684-1685) Yılına Dair Bir Münşeat Mecmuası ve Değerlendirilmesi, Fatih Sultan Mehmet Vakıf Üniversitesi Sosyal Bilimler Enstitüsü, Basılmamış Yüksek Lisans Tezi, İstanbul 2017.

Özcan, Abdülkadir. “Cerehor”, TDVİA, C. 7, İstanbul 1993, ss.393-393.

Özcan, Abdülkadir. "Mustafa II”, TDVIA, C. 31, İstanbul 2006, ss.275280.

Pakalın, M. Zeki. "Cerahor", Osmanlı Tarih Deyimleri ve Terimleri Sözlüğü, C.1, İstanbul 2004, ss.280-280.

Sevinç, Tahir. "Osmanlı Devleti’nin İrşeve Kanalı Projesi (17391741)", History Studies, 8/9, 2013, ss.2201-2216.

Şenyurt, Oya. “Geç Osmanlı İnşaat Ortamında “Bina Eminliği”, METU JFA, 25:2, 2008, ss.151-169.

Topal, Mehmet. Silâhdar Findıklılı Mehmed Ă̆a, Nusretnâme Tahlil ve Metin (1106-1133/1695-1721), Marmara Üniversitesi Sosyal Bilimler Enstitüsü, Basılmamış Doktora Tezi, İstanbul 2001.

Topal, Mehmet. "II. Mustafa'nın Avusturya Seferlerinde Rusçuk Şehri ve Limanının Önemi”, Türklük Araştırmaları Dergisi, S.20, İstanbul 2008, ss.223-250.

Uzunçarşıl1, İ. Hakkı. Osmanlı Devleti Teşkilatından Kapukulu Ocaklarl, C.1, Ankara 1988. 
